\title{
PENGARUH LEVEL PROTEIN PAKAN PADA MASA PERTUMBUHAN TERHADAP PENAMPILAN PADA AWAL PENELURAN AYAM BETINA HASIL PERSILANGAN AYAM KAMPUNG JANTAN DAN AYAM RAS PETELUR BETINA
}

\author{
The effect of dietary protein levels in growing period on performance at onset of lay of \\ crossbred hens between cockerel native chickens and commercial laying hens
}

\author{
Diterima 7 Oktober 2017; diterima pasca revisi 30 Oktober 2017 \\ Layak diterbitkan 31 Oktober 2017
}

Harimurti Februari Trisiwi*

Akademi Peternakan Brahmaputra, Jl. Ki Ageng Pemananhan, Nitikan UH VI/237, Sorosutan, Umbulharjo, Yogyakarta 55162

\begin{abstract}
This research aims were to determine the effects of various dietary protein levels during growing period crossbreed hens between cockerel native chickens and laying hens on performance at onset of lay. The effects of the dietary protein levels on weight and other components of eggs were also examined. Eighteen hens aged thirteen weeks were randomly divided into three different treatment groups wit each group consists of six replications (contains a hen). All the treatment hens were grown in a battery-cage until reaching sexual maturity then were fed with three different dietary protein levels which were 13,54\%, 12,00\%, and 9,80\% formulated with $2600 \mathrm{kcal} / \mathrm{kg}$ $M E$. The collected data were analyzed by a one-way classification of variance analysis (CRD) followed by testing the significant means using The Duncan's Multiple Range Test (DMRT). The experiment result suggested that the treatment during hen's growing period did not cause significance on performance at onset lay, egg weight, and egg components weight.
\end{abstract}

Key words : protein level, performance, onset of lay, egg components

\begin{abstract}
ABSTRAK
Penelitian ini bertujuan untuk mengetahui pengaruh level protein pakan saat pertumbuhan ayam betina hasil persilangan antara ayam kampung jantan dan ayan ras petelur betina dengan mengamati penampilannya saat pertumbuhan dan pengaruhnya terhadap karakteristik awal peneluran. Pengaruh level protein pakan terhadap berat dan komponen-komponen telur juga diteliti. Ayam umur 13 minggu sebanyak 18 ekor dibagi secara acak menjadi 3 kelompok perlakuan. Setiap kelompok terdiri dari 6 ulangan dan setiap ekor ayam adalah 1 ulangan. Ayam dipelihara di kandang baterai sampai mencapai dewasa kelamin mendapat perlakuan pakan terdiri dari 3 level protein, yaitu 13,54\%, 12,00\%, dan 9,80\% dengan $2600 \mathrm{kkal} / \mathrm{kg}$ ME. Variabel yang diteliti adalah konsumsi pakan, pertumbuhan berat abdam, FCR, konsumsi protein, PER, awal peneluran dan berat kuning. Data yang diperoleh dianalisis dengan analisis variansi rancangan acak lengkap pola searah, dan perbedaan rerata perlakuan diuji dengan Duncan's Multiple Range Test (DMRT). Hasil analisis statistik menunjukkan bahwa pemberian 3 level protein tersebut tidak berpengaruh terhadap penampilan awal peneluran, berat telur, dan berat komponen-komponen telur.
\end{abstract}

Kata kunci : pakan, persilangan, ayam kampung jantan, ayam ras petelur betina. 


\section{PENDAHULUAN}

Ayam hasil persilangan antara ayam kampung jantan dan ayam ras betina biasanya dimanfaatkan untuk penyediaan daging ayam yang menyerupai daging ayam kampung. Meskipun demikian, ayam tersebut pada umur 5 bulan dapat menghasilkan telur konsumsi dengan ukuran dan warna yang hampir sama dengan telur ayam ras (Salim, 2013).

Ayam dara umur 12 hingga 20 minggu merupakan periode pertumbuhan reproduksi untuk menuju dewasa kelamin pada umur 20 minggu, tetapi laju pertumbuhan tubuh menurun (Suprijatna, et al., 2006). Pada saat laju pertumbuhan tubuh menurun dan ayam dara belum menghasilkan telur, kebutuhan proteinnya belum maksimal. (Amrullah, 2003).

Beberapa susunan pakan yang banyak digunakan oleh anggota kelompok tani ternak ayam buras di Jawa Tengah mempunyai kandungan protein antara 13 dan $16 \%$ dan energi antara 2200 hingga $2400 \mathrm{kkal} / \mathrm{kg}$ (Muryanto, 2005). Tujuan penelitian ini adalah untuk mengetahui pengaruh level protein rendah saat pertumbuhan ayam betina hasil persilangan antara ayam kampung jantan dan ayan ras petelur betina dengan mengamati penampilannya saat pertumbuhan dan pengaruhnya terhadap karakteristik awal peneluran.

\section{MATERI DAN METODE}

\section{Tempat dan Lama Penelitian}

Penelitian dilakukan di Desa Bangunjiwo, Kecamatan Kasihan, Kabupaten Bantul,

*Corresponding author:

Harimurti Februari Trisiwi

Email : harimurtifebruari@gmail.com

Akademi Peternakan Brahmaputra, Jl. Ki Ageng

Pemananhan, Nitikan UH VI/237, Sorosutan, Umbulharjo,

Yogyakarta 55162
Laboratorium Chem-Mix Pratama, dan Laboratorium Teknologi Hasil Ternak, Fakultas Peternakan, Universitas Gadjah Mada di Sleman. Penelitian berlangsung selama empat bulan yaitu mulai dari persiapan sampai dengan penyusunan laporan.

\section{Kandang dan Ayam}

Kandang yang digunakan adalah kandang baterai dari bambu, setiap petak berukuran 40x $25 \times 40 \mathrm{~cm}^{3}$. Semua petak kandang terletak dalam sebuah bangunan kandang dengan atap genteng dan sebagian genteng kaca. Tiap petak kandang dilengkapi tempat pakan terpisah dari kayu dan tempat minum bersama dari pipa pralon. Ayam yang digunakan adalah ayam betina hasil persilangan ayam kampung jantan dan ayam ras petelur betina berumur 13 minggu yang diperoleh dari peternak di daerah Sleman.

\section{Pakan dan Air Minum}

Kandungan nutrien pakan yang digunakan dalam penelitian ini dihitung berdasarkan Wahju (1985), dan Comfeed, dengan bahan pakan katul, jagung, dedak halus, konsentrat ayam petelur, mineral B-12, Top mix, dan garam dapur. Semua pakan perlakuan disusun dengan energi sekitar $2600 \mathrm{kkal} / \mathrm{kg}$ dan protein yang berbeda. Pakan dan air minum diberikan secara ad libitum. Komposisi dan kandungan nutrien pakan penelitian tercantum pada Tabel 1 .

How to cite:

Trisiwi, H.F. (2017). Pengaruh Level Protein Pakan pada Masa Pertumbuhan terhadap Penampilan pada Awal Peneluran Ayam Betina Hasil Persilangan Ayam Kampung Jantan dan Ayam Ras Petelur Betina. Jurnal Ilmu dan Teknologi Hasil Ternak, 12 (2), 61-68. 


\section{Rancangan Percobaan}

Rancangan yang dipergunakan dalam penelitian ini adalah Rancangan Acak Lengkap dengan tiga macam perlakuan dan enam kali ulangan. Tiap ulangan adalah seekor ayam betina. Ketiga perlakuan yang dicobakan adalah pakan dengan protein kasar (PK) 13,54; 12,00; dan 9,80\% berdasarkan hasil analisis proksimat.

Tabel 1. Komposisi dan Kandungan Nutrien Pakan Perlakuan

\begin{tabular}{lccc}
\hline Bahan pakan (\%) & P1 & P2 & P3 \\
\hline Katul jagung & 70,0 & 70,0 & 70,0 \\
Dedak halus & 5,5 & 15,5 & 24,2 \\
Konsentrat & 24,0 & 14,0 & 4,0 \\
Mineral B-12 & 0,0 & 0,0 & 1,3 \\
Top mix & 0,3 & 0,3 & 0,3 \\
Garam dapur & 0,2 & 0,2 & 0,2 \\
\hline Jumlah & 100,0 & 100,0 & 100,0 \\
\hline Kandungan nutrien & & & \\
PK (\%) & $13,54^{1}$ & $12,00^{1}$ & $9,80^{1}$ \\
ME(kkal/kg) & $2612^{2}$ & $2642^{2}$ & $2659^{2}$ \\
SK $(\%)$ & $5,89^{3}$ & $6,49^{3}$ & $6,91^{3}$ \\
Lemak $(\%)$ & $5,88^{3}$ & $6,78^{3}$ & $7,51^{3}$ \\
Ca $(\%)$ & $2,79^{4}$ & $1,65^{4}$ & $1,15^{4}$ \\
P $(\%)$ & $0,74^{4}$ & $0,76^{4}$ & $0,90^{4}$ \\
\hline Ker & & & \\
\hline
\end{tabular}

Keterangan : ${ }^{1}$ Analisis Lab. Chem-Mix Pratama ${ }^{2}$ Dihitung dari Wahju (1985), Widyani (1989), dan Comfeed. ${ }^{3}$ Dihitung dari Wahju (1985), Analisis PAU-UGM, dan Comfeed. ${ }^{4}$ Dihitung dari Wahju (1985), Comfeed, dan Eka Farma

\section{Variabel yang Diamati}

Variabel yang diamati dalam penelitian ini adalah :

1. Konsumsi pakan : konsumsi pakan diukur setiap minggu yaitu selisih antara jumlah pakan yang disediakan dengan pakan sisa.

2. Pertambahan berat badan : selisih antara berat badan umur 21 minggu dengan 13 minggu.

3. Feed Conversion Ratio (FCR) : perbandingan antara pertambahan berat badan dan konsumsi pakan.

4. Konsumsi protein : perkalian antara konsumsi pakan dengan kandungan PK setiap pakan perlakuan.

5. Protein Efficiency Ratio (PER) :

6. Untuk mengetahui pengaruh perlakuan terhadap penampilan saat dewasa kelamin (awal peneluran) dilakukan pengamatan terhadap umur awal betelur, berat badan saat awal bertelur, dan kualitas telur pertama ( berat telur, tebal kerabang, dan komposisi telur).

7. Berat kuning telur diketahui dengan memisahkan kuning telur dari putih telur setelah telur dipecah, kuning telur digelindingkan pada kertas tisu basah untuk memisahkan putih telur, dan chalazae yang menempel dipotong dengan pisau, kemudian kuning telur ditimbang. Berat kerabang telur didapatkan dengan menimbang kerabang yang sudah dipecah, dicuci dengan air, dan dianginanginkan hingga kering. Berat putih telur didapatkan dari hasil pengurangan berat telur dengan kuning telur dan kerabang telur. Tebal kerabang diukur menggunakan mikrometer dengan ketelitian $0,01 \mathrm{~mm}$ pada bagian 
equator (tengah) kerabang di Laboratorium Teknologi Susu dan Telur, Fakultas Peternakan, UGM.

\section{Analisis Statistika}

Data yang diperoleh dianalisis dengan analisis variansi dari rancangan acak lengkap pola searah, jika terdapat perbedaan dilanjutkan dengan uji Duncan's Multiple Range Test (Astuti, 1980).

\section{HASIL DAN PEMBAHASAN}

\section{Penampilan dan Efisiensi Penggunaan Protein Pakan}

Penggunaan pakan dengan level protein 13,54; 12,00; dan 9,80\% dengan energi 2600 $\mathrm{kkal} \mathrm{ME} / \mathrm{kg}$ tidak berpengaruh terhadap efisiensi penggunaan protein pakan. Hal itu dapat diamati pada variabel PER. Hasil penelitian ini sesuai dengan penelitian Suprijatna et al. (2014), bahwa PER pada ayam arab betina umur 12 hingga 20 minggu dengan PK 12, 15, dan $18 \%$ menunjukkan perbedaan tidak nyata $(\mathrm{P}>0,05)$. Selanjutnya, pada umur 12 hingga 20 minggu telah terjadi laju pertumbuhan yang semakin menurun menjelang tercapainya dewasa kelamin sehingga deposisi protein dalam tubuh menunjukkan penurunan. Menurut Kompiang et al. (2001), ayam kampung dengan pakan pilihan PK 23,06 dan 15,02\% (2900 kkal ME/kg) menghasilkan PER sebesar 0,39 (umur 4 minggu), 0,48 (umur 6 minggu), 0,56 (umur 8 minggu), 0,58 (umur 10 minggu), dan 0,92 (umur 12 minggu).

Tabel 2 menunjukkan bahwa konsumsi protein meningkat nyata $(\mathrm{P}<0,05)$ hingga level protein pakan $12 \%$, sedangkan peningkatannya pada level protein pakan $13,54 \%$ menunjukkan perbedaan tidak nyata $(\mathrm{P}>0,05)$. Hal ini menunjukkan bahwa peningkatan level protein pakan menyebabkan terjadinya kelebihan konsumsi protein. Menurut Boorman (1980), respon positif terhadap input $\mathrm{N}$ merupakan kurva diminishing return. Pakan berprotein lebih tinggi meningkatkan heat increament yang terjadi karena degradasi $\mathrm{N}$ kelebihan asam amino menjadi asam urat (Deschepper and de Groot, 1995). Zhang et al. (1993) menyebutkan bahwa kapasitas usus untuk mengabsorpsi asam amino tinggi sehingga kelebihan asam amino diekskresikan melalui urin ketika kelebihannya dalam darah dan jaringan sangat tinggi.

Tabel 2. Penampilan dan Efisiensi Penggunaan Protein Pakan umur 13 hingga 21 minggu

\begin{tabular}{lccc}
\hline Variabel & P1 & P2 & P3 \\
\hline Konsumsi pakan (g) & 4599,8 & 4820,5 & 5227,7 \\
Berat umur 13 minggu (g) & 1107,7 & 1156,8 & 1237,5 \\
Berat umur 21 minggu (g) & 1698,2 & 1790,8 & 1792,2 \\
Pertambahan berat badan (g) & 590,5 & 634,0 & 554,7 \\
FCR & $8,01^{\mathrm{a}}$ & $7,70^{\mathrm{a}}$ & $9,64^{\mathrm{b}}$ \\
Konsumsi Protein (g) & $622,8^{\mathrm{a}}$ & $578,5^{\mathrm{a}}$ & $512,3^{\mathrm{b}}$ \\
PER & 1,08 & 0,92 & 0,95 \\
\hline
\end{tabular}

Nilai dengan huruf berbeda pada baris yang sama menunjukkan perbedaan nyata $(\mathrm{P}<0,05)$ atau sangat nyata $(\mathrm{P}<0,01)$.

Konsumsi pakan ayam penelitian menunjukkan perbedaan tidak nyata $(\mathrm{P}>0,05)$ meskipun secara kuantitas cenderung meningkat. Hal ini karena perbedaan level protein hanya sebesar 3,74\% dan laju pertumbuhan yang semakin menurun tidak memerlukan penggunaan level protein tinggi. Menurut Widyani (1989), ayam akan makan lebih banyak untuk memenuhi 
kebutuhan asam aminonya, pada kandungan asam amino yang lebih rendah, pakan dikonsumsi lebih banyak. Konsumsi pakan ayam per hari pada penelitian adalah 82,14 g (P1), 86,08 g (P2), dan 93,35 g. Rerata konsumsi pakan ayam ras petelur antara umur 13 hingga 21 minggu, diperhitungkan dari Sudarmono (2007) adalah 81 g/ekor/hari. Konsumsi pakan ayam lokal dengan protein 15-16\% (2750- $2850 \mathrm{kkal}$ $\mathrm{ME} / \mathrm{kg}$ ) adalah 80-100 g/ekor/hari (Iskandar, 2007).

Berat badan umur 13 minggu, 21 minggu, dan pertambahan berat badan pada penelitian ini menunjukkan perbedaan tidak nyata $(\mathrm{P}>0,05)$. Ketiga variabel tersebut hampir sama dengan penampilan ayam ras petelur, tetapi lebih tinggi daripada penampilan ayam kampung betina. Berat ayam ras petelur coklat adalah $1030 \mathrm{~g}$ pada umur 13 minggu dan 1730 g pada umur 21 minggu (Sudarmono, 2007), sedangkan berat badan ayam kampung betina yang dipelihara secara intensif adalah $708 \mathrm{~g}$ pada umur 13 minggu dan 1408 g pada umur 21 minggu
(Iskandar, 2007). Pertambahan berat badan ayam ras petelur diperhitungkan $700 \mathrm{~g}$, sedangkan FCR diperhitungkan berdasarkan konsumsi pakan per hari adalah 6,48.

\section{Penampilan Saat Awal Peneluran}

Pada penelitian ini, ayam mencapai dewasa kelamin yang ditandai dengan bertelur pertama pada umur 160 hari (P1), 157 hari (P2), dan 160 hari (P3). Hasil penelitian ini menunjukkan bahwa level protein pakan mengakibatkan perbedaan yang tidak nyata $(\mathrm{P}>0,05)$. Demikian pula berat badan saat tercapai dewasa kelamin walaupun cenderung meningkat dengan menurunnya level protein, yaitu 1950,5 g (P1), 1970,0 g (P2), dan 2029,7 g (P3), secara statistik menunjukkan perbedaan yang tidak nyata $(\mathrm{P}>0,05)$. Berat badan ayam penelitian ini lebih tinggi daripada berat badan ayam kampung saat bertelur pertama, yaitu 1.650,09 g (Muryanto, 2005), tetapi lebih rendah daripada dara bibit broiler umur 21 minggu, yaitu $2362 \mathrm{~g}$ (Bowmaker and Gous, 1989).

Tabel 3. Penampilan Saat Awal Peneluran

\begin{tabular}{lccc}
\hline Variabel & P1 & P2 & P3 \\
\hline Umur bertelur pertama (hari) & 160 & 157 & 160 \\
Berat badan saat bertelur pertama (g) & 1950,5 & 1970,0 & 2029,7 \\
Kualitas telur pertama : & & & \\
Berat telur (g) & 38,70 & 39,36 & 36,92 \\
Berat albumen (g, \%) & 25,$30 ; 65,37$ & 26,$57 ; 67,51$ & 24,$09 ; 65,25$ \\
Berat yolk (g, \%) & 9,$04 ; 23,36$ & 8,$63 ; 21,93$ & 8,$95 ; 24,24$ \\
Berat kerabang $(\mathrm{g}, \%)$ & 4,$37 ; 11,29$ & 4,$16 ; 10,57$ & 3,$88 ; 10,51$ \\
Tebal kerabang $(\mathrm{mm})$ & 0,36 & 0,33 & 0,32 \\
\hline
\end{tabular}

Hasil penelitian ini menunjukkan bahwa walaupun berat badan ayam hasil persilangan ini dapat digolongkan sebagai ayam petelur berat tetapi mencapai pubertas lebih lambat daripada ayam ras petelur. Sudarmono (2007) menyebutkan bahwa produksi HD (Hen day) sebanyak $5 \%$ ayam ras petelur dicapai pada saat ayam berumur 20 hingga 21 minggu atau 140 hingga 147 hari. Umur dewasa ayam kampung yang dipelihara secara intensif adalah 151 hari (Iskandar, 2007), 196,96 hari (Muryanto, 2005), dan 175 hari pada ayam kampung single comb (Trisiwi, 2014). Hal ini menunjukkan bahwa ayam hasil persilangan ini lebih memiliki karakteristik sebagai ayam lokal, sesuai dengan hasil penelitian Suprijatna et al. (2006) pada ayam Arab. 
Hasil penelitian ini juga menunjukkan perbedaan dibandingkan dengan ayam ras petelur. Suprijatna dan Natawihardja (2014) menunjukkan bahwa pada ayam ras petelur tipe medium (Lohman Brown) umur 12 minggu berat $1012 \mathrm{~g}$, pakan berprotein 12, 15, dan $18 \%$ yang diberikan hingga umur 20 minggu menghasilkan awal peneluran yang bebeda nyata, yaitu 145,42; 141,73; dan 137,50 hari. Peningkatan level protein pakan di atas $12 \%$ tidak mengakibatkan adanya percepatan pertumbuhan untuk mencapai umur dewasa kelamin pada ayam Arab (Suprijatna et al. (2006). Selanjutnya, ayam ras lebih responsif karena telah mengalami perbaikan mutu genetis untuk mencapai dewasa kelamin yang lebih cepat. Bowmaker and Gous (1989) menyebutkan bahwa pada dara bibit broiler selama periode pre-breeding, organ-organ reproduksi berkembang, ukuran hati bertambah dan estrogen yang tergantung pada jalur biosintesis hati diaktifkan.

Hasil penelitian ini menunjukkan bahwa level protein pakan berpengaruh tidak nyata $(\mathrm{P}>0,05)$ terhadap kualitas telur baik berupa berat (telur, albumen, yolk, dan kerabang) maupun terhadap tebal kerabang. Berat telur awal peneluran ini lebih tinggi daripada berat telur awal peneluran ayam kampung, yaitu 32,78 g (Muryanto, 2005). Trisiwi (2014) menunjukkan bahwa ayam kampung single comb umur 211 hari yang diberi pakan berprotein 18,76\% (2750 kkal ME/kg) dan 13,73\% (2780 kkal ME/kg) menghasilkan rerata berat telur yang berbeda tidak nyata $(\mathrm{P}>0,05)$, yaitu 40,42 dan 37,97 g. Hasil penelitian ini juga menunjukkan perbedaan dibandingkan dengan ayam ras petelur. Menurut Penz and Jensen (1991), peningkatan level protein pakan dari 13 menjadi 16\% dengan 2900 kkal ME/kg, menghasilkan berat telur ayam Single Comb White Leghorn yang berbeda sangat nyata $(\mathrm{P}<0,01)$, yaitu 55,9 dan $58,3 \mathrm{~g}$.

Berat dan presentase albumen dan yolk menunjukkan perbedaan tidak nyata $(\mathrm{P}>0,05)$. Walaupun berat dan tebal kerabang secara konsisten lebih rendah pada ayam dengan level protein lebih rendah, perbedaan itu tidak nyata. Pada ayam Leghorn Single Comb, pemberian protein pakan 16 dan 13\% (2900 kkal/kg) menghasilkan perbedaan nyata pada berat telur, albumen, dan yolk, dan perbedaan tidak nyata pada berat kerabang, dengan persentase masingmasing adalah 62,18; 28,00; dan 9,82\% (Penz and Jensen, 1991), dengan berat telur pada umur 20 minggu adalah 40,60 g (Summers, 1993). Menurut Sulandari et al. (2007), berat telur ayam kampung pada awal produksi adalah $37,80 \mathrm{~g}$, dengan 21,67 g albumen (57,33\%), 11,57 g yolk $(30,61 \%)$, dan 4,07 g kerabang $(10,77 \%)$. Tebal kerabang telur ayam kampung yang dipelihara secara intensif antara 0,28 hingga $0,38 \mathrm{~mm}$ (Iskandar, 2007). Tebal kerabang telur ayam Arab dengan protein pakan 18,43\% (2602 kkal $\mathrm{ME} / \mathrm{kg}$ ) pada $\mathrm{Ca} 1,34 ; 2,20$; dan $3,39 \%$ adalah 0,$30 ; 0,35$; dan 0,37\% (Trisiwi, 2010).

Berat dan persentase yolk ayam penelitian ini lebih rendah daripada ayam Leghorn dan ayam kampung kemungkinan karena rendahnya level protein pakan ayam penelitian. Penz and Jensen (1991) menyebutkan bahwa deposisi protein di dalam yolk disintesis di dalam hati dan terus-menerus diakumulasikan di dalam ovum hingga ovulasi terjadi. Fungsi hati tidak hanya untuk mensintesis protein yolk, tetapi juga untuk metabolisme dan cadangan nutrien, sintesis dan degradasi sel-sel darah, dan menghasilkan protein-protein plasma (Hiramoto et al., 1990).

Persentase albumen telur pada penelitian ini lebih tinggi daripada telur ayam ras maupun ayam kampung. Dengan berat telur ayam penelitian yang berbeda tidak nyata dan hampir sama dengan berat telur ayam kampung pada awal produksi, kemungkinan ayam dapat mempertahankan ukuran telur. Penelitian Hiramoto et al. (1990) menunjukkan bahwa sintesis protein di dalam jaringan (g/hari) pada pakan kontrol adalah 44,3 (seluruh tubuh), 7,4 (hati), 4,0 (magnum), dan 1,3 (oviduct lainnya). Penurunan sintesisnya di dalam magnum dan bagian oviduct lainnya lebih besar daripada di seluruh tubuh ketika pakan defisien asam-asam 
amino sehingga menghasilkan perbedaan nyata pada berat telur, albumen, dan yolk.

\section{KESIMPULAN}

Dari hasil penelitian dapat disimpulkan bahwa pertumbuhan ayam betina hasil persilangan ayam kampung jantan dan ayam ras petelur betina umur 13 hingga 21 minggu dengan kandungan protein 9,80 hingga $12,00 \%$ pada kandungan energi $2600 \mathrm{kkal} \mathrm{ME} / \mathrm{kg}$ cukup efisien. Level protein pakan yang meningkat tidak meningkatkan laju pertumbuhan dan percepatan dewasa kelamin sehingga tidak berdampak nyata terhadap penampilan saat awal peneluran.

\section{DAFTAR PUSTAKA}

Amrullah. (2003). Nutrisi Ayam Petelur. Satu Gunung budi. Bogor.

Astuti, M. (1980). Rancangan Percobaan \& Analisis Statistik. Bagian Pemuliaan Ternak, Fakultas Peternakan UGM. Yogyakarta.

Boorman, K. N. (1980). Dietary Constraints on Nitrogen Retention. Protein Deposition in Animals. Butterworths. London, Boston, Sydney, Wellington, Durban, Toronto.

Bowmaker, J. E., \& Gous, R. M. (1989). Quantification of reproductive changes and nutrients requirements of broiler breeder pullets at sexual maturity. British Poultry Science, $\quad 30(3), \quad 663-675$. http://dx.doi.org/10.1080/00071668908417 189
Deschepper, K., \& de Groote, G. (1995). Effect of dietary protein, essential \& non-essential amino acids on the performance and carcase composition of male broiler chickens. British Poultry Science, 36(2), 229-245.

https://doi.org/10.1080/0007166950841777 $\underline{2}$

Hiramoto, K., Muramatsu, T., \& Okumara, J. (1990). Effect of methionine \& lysine deficiencies on protein synthesis in the liver and oviduct and in the whole body of laying hens. Poultry Science, 69(1), 84-9. https://doi.org/10.3382/ps.0690084

Iskandar, S. (2007). Tatalaksana Pemeliharaan Ayam Lokal. Dalam : Keanekaragaman Sumber Daya Hayati Ayam Lokal Indonesia. Pusat Penelitian Biologi, LIPI. Bandung.

Kompiang, I. P., Togatorop, M., \& Jarmani, \& S. (2001). Kinerja ayam kampung dengan sistem pemberian pakan secara memilih dengan bebas. Jurnal Ilmu Ternak dan Veteriner, 6 (2), 94-101.

Muryanto. (2005). Evaluasi Hasil-Hasil Penelitian dan Pengembangan pada Ayam Buras. Prosiding Lokakarya Nasional Inovasi Teknologi Pengembangan Ayam Lokal. Pusat Penelitian dan Pengembangan Peternakan. Bogor.

Penz J. A. M., \& Jensen, L. S. (1991). Influence of protein concentration, amino acid supplementation, \& daily time to access to high- or low-protein diets on egg weight \& components in laying hens. Poultry Science, $\quad 70(12)$, 2460-6. https://doi.org/10.3382/ps.0702460 
Salim, E. (2013). Ayam Kampung Super. Lily Publisher. Yogyakarta.

Sudarmono, A. S. (2007). Pedoman Pemeliharaan Ayam Ras Petelur. Kanisius. Yogyakarta.

Sulandari, S., Zein, M. S. A., Paryanti, S. T. Sartika, M. Astuti, T. Widjastuti, E., Sudjana, S., Darana, I., Setiawan \& Garnida., D. (2007). Sumberdaya Genetik Ayam Lokal Indonesia. Prosiding Seminar Keanekaragaman Sumber Daya Hayati Ayam Lokal Indonesia : Manfaat dan Potensi. Pusat Penelitian Biologi, Lembaga Ilmu Pengetahuan Indonesia. Bandung.

Summers, J. D. (1993). Influence of prelay treatment and dietary protein level on the reproductive performance of white leghorn hens. Poultry Science, 72 (9), 1705-1713. https://doi.org/10.3382/ps.0721705

Suprijatna, E., \& Natawihardja, D. (2014) Pengaruh taraf protein dalam ransum pada periode pertumbuhan terhadap performan ayam ras petelur tipe medium saat awal peneluran. Journal of the Indonesian Tropical Animal Agriculture, 29 (1), 33-38.
Suprijatna, E., Mahfudz, L. D., \& Saputra, D. H. (2006). Pengaruh level protein ransum saat pertumbuhan terhadap efisiensi penggunaan protein dan performan awal peneluran pada ayam arab. Journal of the Indonesian Tropical Animal Agriculture, 31 (2), 111-116.

Trisiwi. H. F. (2010). Pengaruh kalsium pakan terhadap kualitas kerabang dan penggunaan kalsium ayam arab. Jurnal Agrisains, 11 (2), 74-79.

Trisiwi. H. F. (2014). Penampilan Ayam Kampung Single Comb Terpilih dengan Suplementasi Asam Amino Esensial pada Pakan Berprotein Rendah. Jurnal Agrisains, 5 (2), 137-147.

Wahju, J. (1985). Ilmu Nutrisi Unggas. Gadjah Mada Universitisi Unggas. Gadjah Mada University Press. Yogyakarta.

Zhang, Y., Herro , D. R., \& Parsons, C. R. (1993). Effect of crystalline lysine and methionine intake on amino acid excretion by precision-fed cockerels. Poultry Science Journal, 72(6), 1180-1183. https://doi.org/10.3382/ps.0721180 